Uji aktivitas antioksidan ekstrak daun kalba ..... (Undri Rastuti dan Purwati)

\title{
UJI AKTIVITAS ANTIOKSIDAN EKSTRAK DAUN KALBA (Albizia falcataria) DENGAN METODE DPPH(1,1-Difenil-2-pikrilhidrazil) DAN IDENTIFIKASI SENYAWA METABOLIT SEKUNDERNYA
}

\author{
Undri Rastuti dan Purwati \\ Program Studi Kimia, Jurusan MIPA, Fakultas Sains dan Teknik, \\ Universitas Jenderal Soedirman \\ e-mail: undrirasuti@yahoo.co.id
}

\begin{abstract}
ABSTRAK
Telah dilakukan penelitian uji aktivitas antioksidan ekstrak daun kalba pada pelarut nheksana, etil asetat dan metanol serta mengidentifikasi golongan senyawa metabolit sekundernya. Hasil maserasi diperoleh ekstrak n-heksana (E1), etil asetat (E2) dan metanol (E3) daun kalba berbentuk pasta dengan rendemen masing-masing ekstrak adalah 2,49, 5,08 dan 5,32\% (b/b). Uji aktivitas antioksidan E1, E2, E3 memiliki nilai ES 50 masingmasing sebesar 1338,758, 473,756 dan 264,519 ppm. Ekstrak metanol daun kalba memilki aktivitas antioksidan paling tinggi. Uji senyawa metabolit sekunder pada ekstrak metanol daun kalba menunjukkan senyawa metabolit sekunder golongan terpenoid, flavonoid dan fenolat. Hasil analisis menggunakan spektrofotometer UV-Vis menunjukkan adanya gugus kromofor $\mathrm{C}=\mathrm{C}$ dan hasil analisis menggunakan spektrofotometer IR menunjukkan bahwa ekstrak metanol daun kalba memiliki gugus fungsi $\mathrm{O}-\mathrm{H}, \mathrm{C}-\mathrm{H}$ alifatik, $\mathrm{C}=\mathrm{C}$ alkena dan $\mathrm{C}=\mathrm{C}$ aromatic.
\end{abstract}

Kata kunci : maserasi, antioksidan, DPPH

\section{ANTIOXIDANT ACTIVITY EXPERIMENT OF KALBA'S (Albizia falcataria) LEAVE EXTRACT WITH DPPH (1,1-Diphenyl-2-picrylhydrazyl) METHOD AND IDENTIFICATION OF CHEMICAL COMPOUNDS}

\begin{abstract}
Determination of antioxidant activity from Kalba's leaves extracts had been done in nhexane, ethyl acetate, and methanol solvent. The identification of secondary metabolite compounds had also been done. The maceration of Kalba leaves produced n-hexane (E1), ethyl acetate (E2) and methanol extracts in pasta form with yield of each extract 2,49\% $(\mathrm{w} / \mathrm{w}), 5,08 \%(\mathrm{w} / \mathrm{w})$ and $5,32 \%(\mathrm{w} / \mathrm{w})$. The determination of antioxidant activity for E1, $\mathrm{E} 2$, E3 had a value $\mathrm{ES}_{50}$ respectively was $1338.758 \mathrm{ppm}, 473.756 \mathrm{ppm}$ and $264.519 \mathrm{ppm}$. Compounds secondary metabolites in methanol extracts of kalba leaves showed terpenoid, flavonoids and phenolic class. The analysis using UV-Vis spectrophotometer showed chromophore $\mathrm{C}=\mathrm{C}$ group and the analysis using IR spectrophotometer showed that methanol extract of kalba leaves has $\mathrm{O}-\mathrm{H}$ functional groups, aliphatic $\mathrm{CH}, \mathrm{C}=\mathrm{C}$ alkene, aromatic $\mathrm{C}=\mathrm{C}$.
\end{abstract}

Keyword : maceration, antioxidant, DPPH 


\section{PENDAHULUAN}

Kalba merupakan spesies asli dari kepulauan sebelah timur Indonesia yakni di sekitar Maluku dan Irian Jaya. Namun, tanaman ini sekarang sudah menyebar dan banyak dikenal oleh masyarakat karena tanaman ini mudah beradaptasi dan mudah menyesuaikan diri untuk tumbuh dan berkembang (Atmosuseno, 1997). Masyarakat pada awalnya mengenal tanaman ini tak lebih dari sekedar pohon yang kayunya dapat digunakan sebagai kayu bakar, daunnya hanya digunakan sebagai makanan ternak, dan pohonnnya digunakan sebagai peneduh di perkebunan teh, kopi, atau vanili (Kusriniati, 2007). Pemanfaatan pohon kalba pada saat ini terbatas pada penggunaan kayunya sebagai bahan bangunan, sedangkan daun belum mendapatkan perhatian yang berarti.

Menurut Harbone (1996), daun tumbuhan umumnya mengandung senyawa aktif dalam bentuk metabolit sekunder seperti alkaloid, flavonoid, steroid, triterpenoid, kumarin dan lainlain. Beberapa tanaman yang berbau menusuk seperti petai, takokak, dan bawang diketahui mempunyai aktivitas antioksidan yang tinggi (Cholishoh dan Utami, 2008). Menurut Cholishoh dan Utami (2008), kandungan suatu tanaman dalam satu familia biasanya tidak berbeda jauh. Hasil penelitian Rastuti dan Purwati (2010), menunjukkan degradasi lignin serbuk gergaji kayu kalba mempunyai aktivitas sebagai antioksidan. Sedangkan ekstrak metanol kulit batang kalba juga menunjukkan aktivitas antioksidan yang kuat dengan $\mathrm{ES}_{50}$ 156,51 ppm (Purwati dan Rastuti, 2011). Jika pada bagian kayu dan kulit batang kalba mempunyai aktivitas sebagai antioksidan tidak tertutup kemungkinan ditemukannya senyawa lain yang juga memiliki aktivitas sebagai antioksidan pada bagian tumbuhan yang lain, yaitu pada daun tumbuhan ini. Oleh karena itu, daun kalba yang belum banyak dimanfaatkan perlu diidentifikasi kandungan kimianya, sehingga dapat didaya gunakan.

Berdasarkan latar belakang di atas, pada penelitian ini dilakukan uji aktivitas antioksidan dan identifikasi senyawa metabolit sekunder dari ekstrak daun kalba. Metode uji aktivitas antioksidan yang digunakan pada penelitian ini adalah metode DPPH $(1,1$ Difenil-2-pikrilhidrazil). Metode DPPH memberikan informasi reaktivitas senyawa yang diuji dengan suatu radikal stabil. DPPH memberikan serapan kuat pada panjang gelombang $517 \mathrm{~nm}$ dengan warna violet gelap (Sunarni, 2005). Metode DPPH merupakan metode yang sederhana, cepat, dan mudah untuk skrining aktivitas penangkap radikal beberapa senyawa, selain itu metode ini terbukti akurat dan praktis (Prakash et al., 2001).

Tahapan penelitian yang dilakukan adalah serbuk daun kalba, dimaserasi dengan menggunakan tiga pelarut secara berturut-turut yaitu nheksana, etil asetat, dan metanol. Ketiga ekstrak dari daun kalba, diuji aktivitas antioksidannya menggunakan metode DPPH. Ekstrak daun kalba yang mempunyai aktivitas antioksidan paling tinggi kemudian diidentifikasi kandungan golongan senyawa metabolit sekundernya menggunakan pereaksi warna pada KLT, spektrofotometer infra merah dan UVvisible.

\section{METODE PENELITIAN}

\section{Alat dan Bahan}

Alat-alat yang digunakan antara lain: alat-alat gelas, blender, oven, timbangan analitik, alat rotary evaporator Buchii, waterbath, filler, pipet ukur, pipa kapiler, hot plate, seperangkat alat KLT, lampu UV Cabinet II $254 \mathrm{~nm}$ dan $366 \mathrm{~nm}$, alat spektrofotometer UV- 
Vis Shimadzu UV 1601 SA, dan spektrofotometer IR Shimadzu FTIR8201 PC.

Bahan-bahan yang digunakan antara lain: daun kalba, n-heksana, etil asetat, metanol, Dimetil Sulfonat (DMSO), akuades, 1,1-Difenil-2Pikrilhidrazil (DPPH), Butil Hidroksi Toluen (BHT), pereaksi $\mathrm{FeCl}_{3} 5 \%$, pereaksi vanillin- $\mathrm{HCl}$, pereaksi Dragendorf, $\mathrm{I}_{2}$, plat KLT silika gel $\mathrm{GF}_{254}$, kertas saring, dan tisue.

\section{Prosedur Penelitian}

\section{a. Ekstraksi Daun Kalba}

Daun kalba dikeringkan tanpa terkena sinar matahari secara langsung, dihaluskan dengan diblender hingga menjadi serbuk. Tiga ratus gram serbuk daun kalba dimaserasi secara berturutturut dengan pelarut n-heksana, etil asetat dan metanol. Masing-masing ekstrak yang diperoleh diuapkan pelarutnya hingga diperoleh ekstrak pekat daun kalba larut heksana (E1), larut etil asetat (E2) dan larut metanol (E3).

\section{b. Uji Aktivitas Antioksidan dengan Metode DPPH}

1) Pembuatan Larutan DPPH (Molyneux, 2004)

Sebanyak 1,97 mg DPPH dilarutkan dengan metanol dalam labu ukur sampai $100 \mathrm{~mL}$ sehingga diperoleh larutan dengan konsentrasi 0,05 mM.

2) Pembuatan Larutan Uji E1, E2, E3

Sebanyak 50 mg E1, E2, E3 masing-masing dilarutkan dengan $50 \mathrm{~mL}$ metanol dalam labu ukur $50 \mathrm{~mL}$ sehingga diperoleh konsentrasi 1000 ppm (larutan induk). Kemudian dilakukan pengenceran dalam labu ukur 10 $\mathrm{mL}$ dengan menambahkan metanol sehingga diperoleh larutan uji dengan konsentrasi 100, 400, 800, 1200, dan 1600 ppm.

3) Penentuan Panjang Gelombang Serapan Maksimum DPPH (Molyneux, 2004)

Sebanyak $4 \mathrm{~mL}$ larutan DPPH $0,05 \mathrm{mM}$ dan ditambahkan dengan $1 \mathrm{~mL}$ metanol. Setelah dibiarkan selama 30 menit ditempat gelap, serapan larutan diukur dengan spektrofotometer $\mathrm{UV}-\mathrm{V}$ is pada panjang gelombang 400-600 nm.

4) Penentuan Operating time Larutan Uji E1, E2, E3

Penentuan operating time dilakukan dengan cara $4 \mathrm{~mL}$ larutan DPPH 0,05 mM ditambah dengan $1 \mathrm{~mL}$ larutan uji $100 \mathrm{ppm}$ (larutan uji E1, E2, E3). Larutan tersebut diukur absorbansinya pada panjang gelombang maksimum yang telah diperoleh dengan interval waktu 5 menit sampai diperoleh absorbansi yang stabil dan tidak terlihat adanya penurunan absorbansi.

5) Penentuan Aktivitas Antioksidan

Penentuan aktivitas antioksidan dilakukan dengan cara $4 \mathrm{~mL}$ larutan DPPH 0,05 mM ditambah dengan masing-masing $1 \mathrm{~mL}$ larutan uji E1, E2, E3 konsentrasi 100, 400, 800, 1200, dan 1600 ppm. Campuran didiamkan selama waktu operating time yang telah diperoleh. Larutan ini kemudian diukur absorbansinya pada panjang gelombang maksimum. Sebagai pembanding digunakan BHT konsentrasi 10, 20, 30, 40 dan 50 ppm dengan 
perlakuan yang sama dengan larutan uji.

6) Penentuan Persentase Peredaman

Persen peredaman

$$
=\frac{\mathrm{A}_{1}-\mathrm{A}_{2}}{\mathrm{~A}_{1}} \times 100 \%
$$

$\mathrm{A}_{1}=$ absorbansi kontrol

$\mathrm{A}_{2}=$ absorbansi sampel

Nilai $\mathrm{ES}_{50}$ merupakan bilangan yang menunjukkan konsentrasi sampel uji yang memberikan peredaman sebesar 50\% (mampu menghambat atau meredam proses oksidasi sebesar 50\%). Nilai $\mathrm{ES}_{50}$ ditentukan dengan cara dibuat kurva linear antara konsentrasi larutan uji (sumbu $\mathrm{x}$ ) dan $\%$ peredaman (sumbu y).

\section{c. Penentuan Eluen Terbaik menggunakan KLT}

Ekstrak daun kalba yang memiliki aktivitas antioksidan paling tinggi dipisahkan dengan KLT menggunakan silika gel $\mathrm{GF}_{254}$. Pengamatan spot dilakukan menggunakan lampu UV Cabinet II $254 \mathrm{~nm}$ dan ditentukan nilai Rf nya. KLT dilakukan sampai diperoleh perbandingan eluen yang memberikan pemisahan terbaik, selanjutnya KLT dengan eluen terbaik digunakan untuk uji metabolit sekunder.

\section{d. Identifikasi Golongan Senyawa Kimia Daun Kalba}

1) Uji Metabolit Sekunder (Harbone, 1987)

Ekstrak daun kalba yang memiliki aktivitas antioksidan paling tinggi diidentifikasi senyawa metabolit sekundernya dengan uji fitokimia menggunakan KLT dengan eluen terbaik. Senyawa metabolit sekunder yang diuji adalah alkaloid, terpenoid, flavonoid dan fenolat.
2) Analisis Spektrofotometer UV-Vis dan IR.

Ekstrak daun kalba yang memiliki aktivitas antioksidan paling tinggi dianalisis menggunakan Spektrofotometer UV-Vis dan IR.

\section{HASIL DAN PEMBAHASAN}

\section{a. Ekstraksi Daun Kalba}

Sampel daun kalba dikeringkan, selanjutnya dihaluskan dengan blender supaya ukuran partikelnya lebih kecil, memperluas kontak dan meningkatkan daya interaksinya dengan pelarut, sehingga jumlah ekstrak yang diperoleh optimum.

Maserasi dilakukan secara bertingkat dengan pelarut n-heksana, etil asetat dan metanol. Ekstraksi dengan pelarut n-heksana bertujuan untuk menarik senyawa non polar, etil asetat untuk menarik senyawa yang bersifat kurang polar (semi polar) dan metanol untuk menarik senyawa kimia yang bersifat polar. Ketiga ekstrak kemudian dipekatkan, sehingga diperoleh ekstrak pekat berbentuk pasta seperti pada Tabel 1.

\section{b. Uji Aktivitas Antioksidan dengan Metode DPPH}

1. Penentuan panjang gelombang maksimum

Penentuan panjang gelombang maksimum bertujuan untuk mengetahui panjang gelombang yang mempunyai serapan maksimum, yaitu saat senyawa berwarna yang terbentuk telah optimum sehingga diperoleh kepekaan yang maksimum tersaji pada Gambar 1.

Gambar 1 menunjukkan bahwa panjang gelombang maksimum untuk larutan DPPH 0,05 $\mathrm{mM}$ yang diperoleh adalah pada panjang gelombang $516 \mathrm{~nm}$ dengan nilai absorbansi 0,3604. 
Tabel 1. Hasil ekstraksi 300 gram serbuk daun kalba

\begin{tabular}{|c|c|c|c|c|}
\hline Nama ekstrak & Warna & Bentuk & Berat ekstrak(g) & Rendemen(\% b/b) \\
\hline E1 & Hijau & Pasta & 7,46 & 2,49 \\
\hline E2 & Hijau & Pasta & 15,23 & 5,08 \\
\hline E3 & Cokelat & Pasta & 15,97 & 5,32 \\
\hline
\end{tabular}

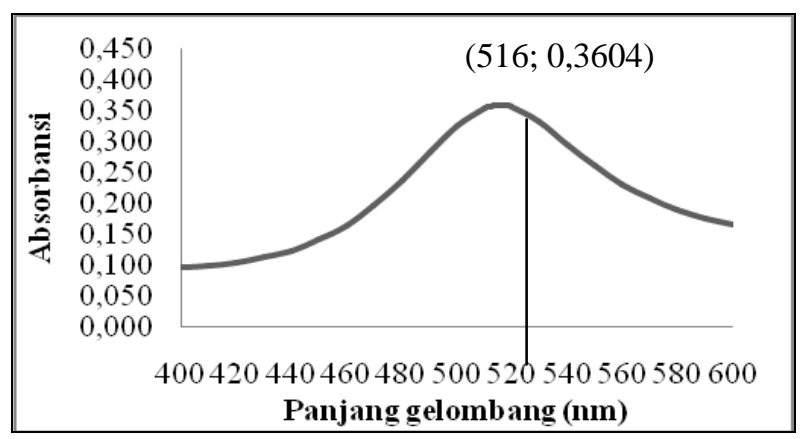

Gambar 1 . Panjang gelombang maksimum DPPH 0,05 M

\section{Penentuan Operating Time}

Operating time (OT) digunakan untuk menentukan waktu paling tepat larutan uji dalam meredam radikal bebas DPPH. Operating time ini menunjukkan

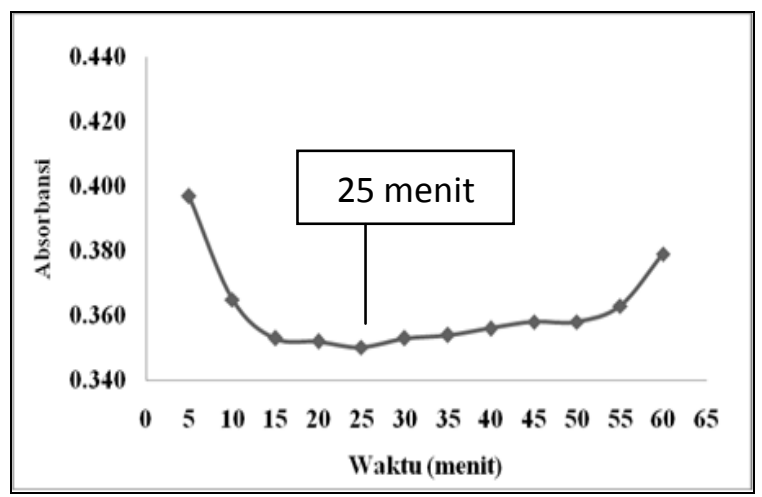

Gambar 2. Penentuan OT larutan uji E1 bahwa reaksi antara larutan uji dan DPPH telah sempurna. Grafik penentuan operating time masing-masing larutan uji (E1, E2, E3) disajikan pada Gambar 2, 3, dan 4.

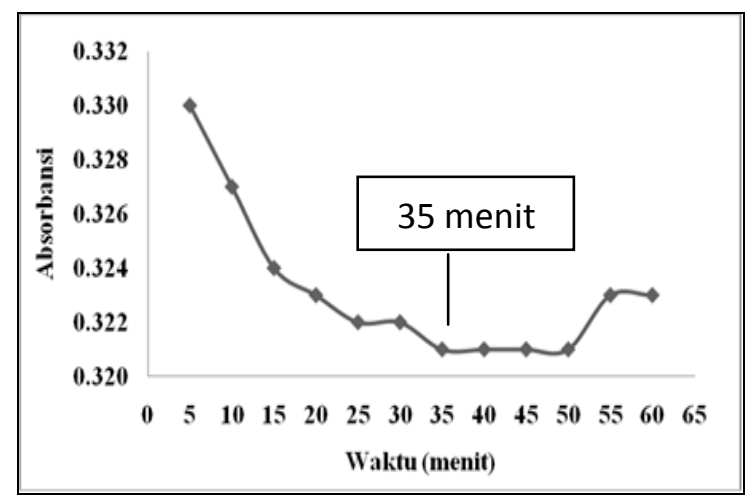

Gambar 3. Penentuan OT larutan uji E2

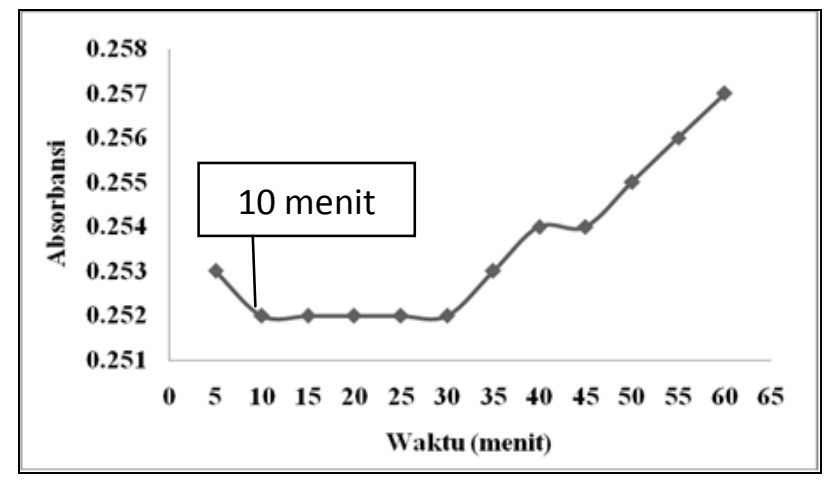

Gambar 4. Penentuan OT larutan uji E3 
3. Penentuan aktivitas antioksidan

Aktivitas antioksidan dari larutan uji E1, E2 dan E3 dapat dianalisis dari data hasil pengukuran absorbansi DPPH berturut-turut pada menit ke-25, 35 dan 10 menit dengan adanya penambahan masing-masing larutan uji ekstrak daun kalba dan BHT yang dibandingkan terhadap kontrol DPPH. Nilai absorbansi yang diperoleh digunakan untuk menghitung persentase peredaman yaitu dengan menggunakan persamaan (1). Grafik hubungan konsentrasi larutan uji (ppm) dengan persen peredaman dapat diperoleh dengan memplot nilai dari persen peredaman dan konsentrasi larutan uji yang dapat dilihat pada Gambar 5, 6, 7 masing-masing untuk E1, E2, E3 daun kalba dan Gambar 8 untuk BHT.

Persen peredaman $=\frac{A_{1}-A_{2}}{A_{1}} \times 100 \%$

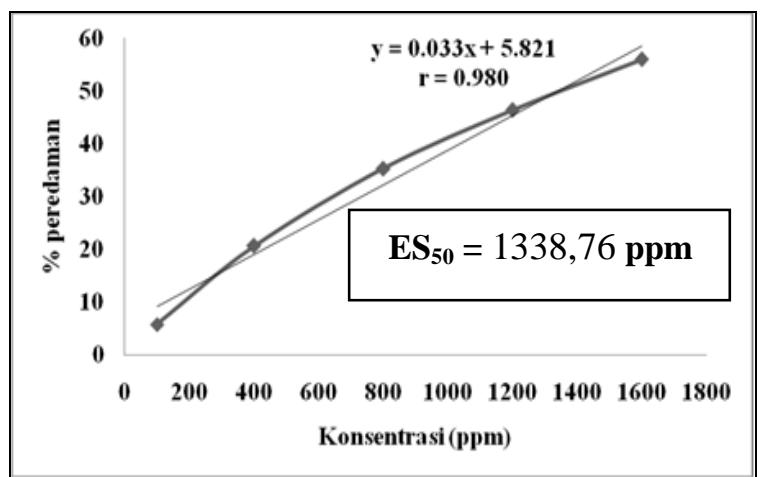

Gambar 5. Pengaruh konsentrasi terhadap $\%$ peredaman larutan uji E1

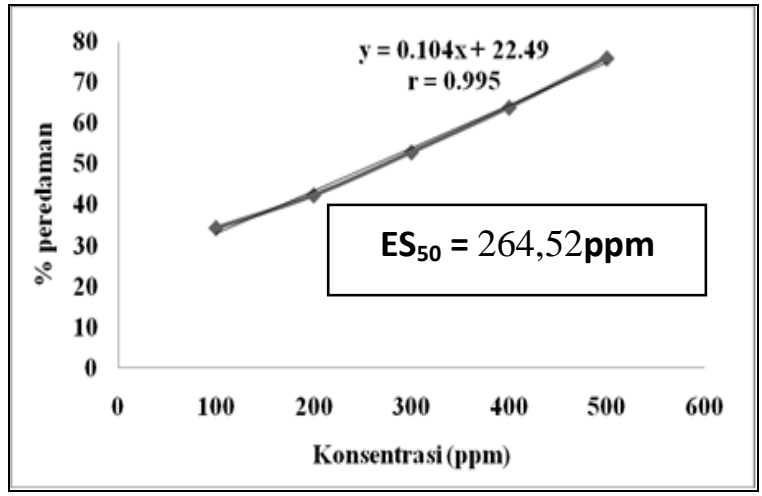

Gambar 7. Pengaruh konsentrasi terhadap $\%$ peredaman larutan uji E3
Berdasarkan Gambar 5, 6, 7 dan 8, menunjukkan bahwa ketiga ekstrak daun kalba yaitu ekstrak n-heksan, ekstrak etil asetat, dan ekstrak metanol mempunyai aktivitas antioksidan yang lemah karena mempunyai $\mathrm{ES}_{50}$ lebih dari $200 \mathrm{ppm}$. Menurut Blouis (1958), suatu senyawa dikatakan berpotensi sebagai antioksidan kuat jika memiliki nilai $\mathrm{ES}_{50}$ kurang dari 200 ppm. Antioksidan BHT memiliki nilai $\mathrm{ES}_{50}$ yang lebih kecil dari ekstrak metanol daun kalba yaitu 20,75 ppm. Hal ini menunjukkan bahwa BHT sebagai pembanding positif memiliki aktivitas antioksidan yang lebih tinggi dari ekstrak metanol daun kalba. Ekstrak metanol daun kalba mempunyai aktivitas antioksudan yang paling tinggi dibanding kedua ektrak yang lain, yaitu dengan nilai $\mathrm{ES}_{50}=264,52 \mathrm{ppm}$.

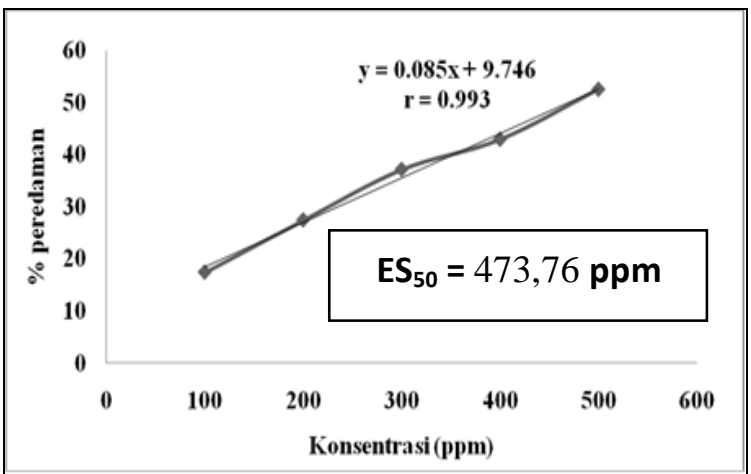

Gambar 6. Pengaruh konsentrasi terhadap $\%$ peredaman larutan uji E2

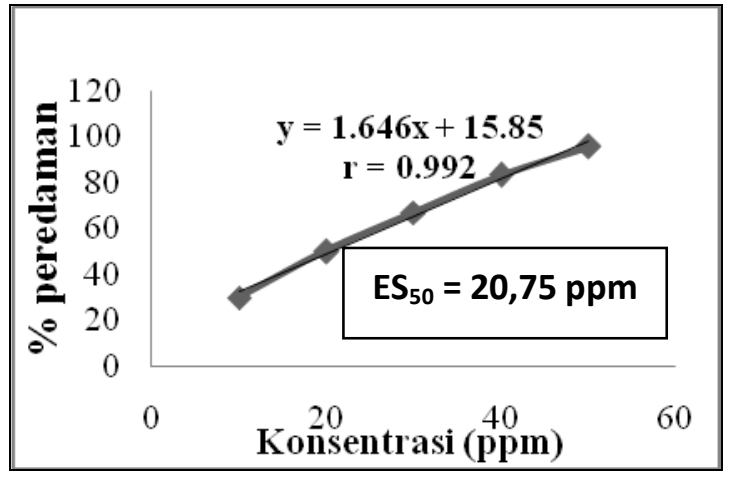

Gambar 8. Pengaruh konsentrasi terhadap $\%$ peredaman larutan BHT 
Tabel 2. Variasi komposisi eluen pada penentuan eluen terbaik ekstrak metanol daun kalba

\begin{tabular}{|c|c|l|c|}
\hline $\begin{array}{c}\text { Perbandingan } \\
\text { eluen (K:EA*) }\end{array}$ & $\begin{array}{c}\text { Noda pada } \\
\text { lampu UV }\end{array}$ & \multicolumn{1}{|c|}{ Rf } & Keterangan \\
\hline $5: 5$ & 4 & 0,$2 ; 0,3 ; 0,6 ; 0,8$ & $\begin{array}{c}\text { Noda belum terpisah } \\
\text { dengan baik }\end{array}$ \\
\hline $4: 6$ & 5 & 0,$1 ; 0,2 ; 0,4 ; 0,7 ; 0,9$ & $\begin{array}{c}\text { Noda belum terpisah } \\
\text { dengan baik }\end{array}$ \\
\hline $3: 7$ & 6 & $\begin{array}{l}0,3 ; 0,4 ; 0,5 ; 0,6 ; 0,6 \\
; 0,8\end{array}$ & $\begin{array}{l}\text { Noda terpisah cukup baik } \\
; 0,9 ; 0,4 ; 0,5 ; 0,5 ; 0,6\end{array}$ \\
\hline $2: 8$ & 6 & $\begin{array}{l}\text { Noda terpisah dengan } \\
\text { baik dan jarak berjauhan }\end{array}$ \\
\hline $1: 9$ & 5 & 0,$3 ; 0,5 ; 0,6 ; 0,7 ; 0,9$ & $\begin{array}{c}\text { Noda terpisah dengan } \\
\text { baik }\end{array}$ \\
\hline
\end{tabular}

* $\mathrm{K}=$ kloroform, $\mathrm{EA}=$ etil asetat

\section{b. Penentuan Pemisahan Terbaik dengan Kromatografi Lapis Tipis}

Pemisahan komponen senyawa yang terbaik dengan KLT menggunakan eluen campuran kloroform dan etil asetat. Variasi komposisi eluen yang digunakan dalam penentuan eluen terbaik dengan KLT disajikan pada Tabel 2 dan hasil pemisahan terbaik adalah dengan eluen kloroform:etil asetat (2:8).

\section{c. Uji Metabolit Sekunder}

Uji metabolit sekunder terhadap E3 dilakukan menggunakan pereaksi warna pada plat KLT dengan eluen terbaik kloroform:etil asetat (2:8). Hasil uji metabolit sekunder terhadap ekstrak metanol daun kalba disajikan pada Tabel 3.

$6 \mathrm{ArOH}+\mathrm{FeCl}_{3} \rightarrow\left[\mathrm{Fe}(\mathrm{OAr})_{6}\right]^{3-}+3 \mathrm{HCl}+3 \mathrm{H}^{+}$

Kompleks berwarna

(hijau, hitam, biru tua)
Prinsip uji vanillin-HCl yaitu vanilin terprotonasi dalam larutan asam dan menghasilkan karbokation. Karbokation ini bereaksi dengan flavonoid. Senyawa antara yang dihasilkan mengalami reaksi dehidrasi dan menghasilkan senyawa berwarna ungu atau merah (Salunkhe et al., 2002). Uji positif senyawa fenolat ditunjukkan dengan terbentuknya bercak warna hitam setelah disemprot $\mathrm{FeCl}_{3} \quad 5 \%$ (b/v). Penambahan $\mathrm{FeCl}_{3} \quad 5 \%$ hanya dapat menunjukkan keberadaan senyawa fenolat secara umum, namun tidak dapat membedakan golongannya. Menurut Harborne (1996), hasil positif adanya senyawa fenolat ditunjukkan dengan terbentuknya kompleks berwarna hijau, ungu, biru, atau hitam.

Tabel 3. Hasil uji metabolit sekunder terhadap ekstrak metanol daun kalba

\begin{tabular}{|c|c|c|c|c|}
\hline $\begin{array}{c}\text { Senyawa yang } \\
\text { diidentifikasi }\end{array}$ & Pereaksi & $\begin{array}{c}\text { Warna noda } \\
\text { mula-mula }\end{array}$ & $\begin{array}{c}\text { Warna noda } \\
\text { setelah disemprot }\end{array}$ & Keterangan \\
\hline Alkaloid & Dragendorff & - & - & negatif \\
\hline Terpenoid & Uap $\mathrm{I}_{2}$ & Kuning & Cokelat & positif \\
\hline Flavonoid & Vanilin-HCl & Tidak berwarna & Ungu & positif \\
\hline Fenolat & $\mathrm{FeCl}_{3}$ & Tidak berwarna & Hitam & positif \\
\hline
\end{tabular}




\section{d. Identifikasi Menggunakan Spektrofotometer UV-Vis dan Infra Merah (IR)}

daun kalba menggunakan spektrofotometer UV-Vis memberikan dua puncak serapan seperti pada Gambar 10. Berdasarkan hasil analisis spektrofotometer UV-Vis terdapat tiga serapan maksimum yaitu serapan pertama yaitu pada panjang gelombang $205 \mathrm{~nm}$ diduga merupakan serapan dari pelarut metanol. Menurut Silverstein et al., (1986), batas terendah kebeningan dari metanol dekat $205 \mathrm{~nm}$. Serapan kedua pada panjang gelombang 220-230 nm yaitu puncak lemah (bahu) dan serapan ketiga yaitu pada panjang gelombang 275 nm. Menurut Khopkar (2007), transisi yang terjadi pada rentang panjang gelombang 186-280 $\mathrm{nm}$ menunjukan adanya gugus kromofor $(\mathrm{C}=\mathrm{C})$ dimana terjadi transisi elektron dari $\mathrm{n} \rightarrow \pi^{*}$ atau $\pi \rightarrow \pi^{*}$.

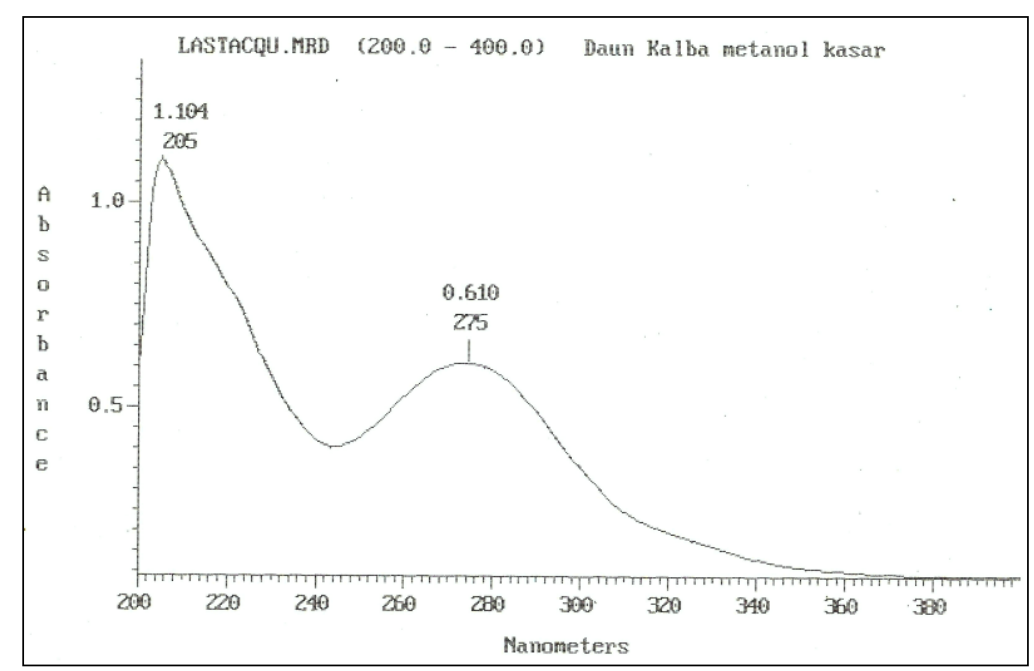

Gambar 10. Spektrum UV ekstrak E3

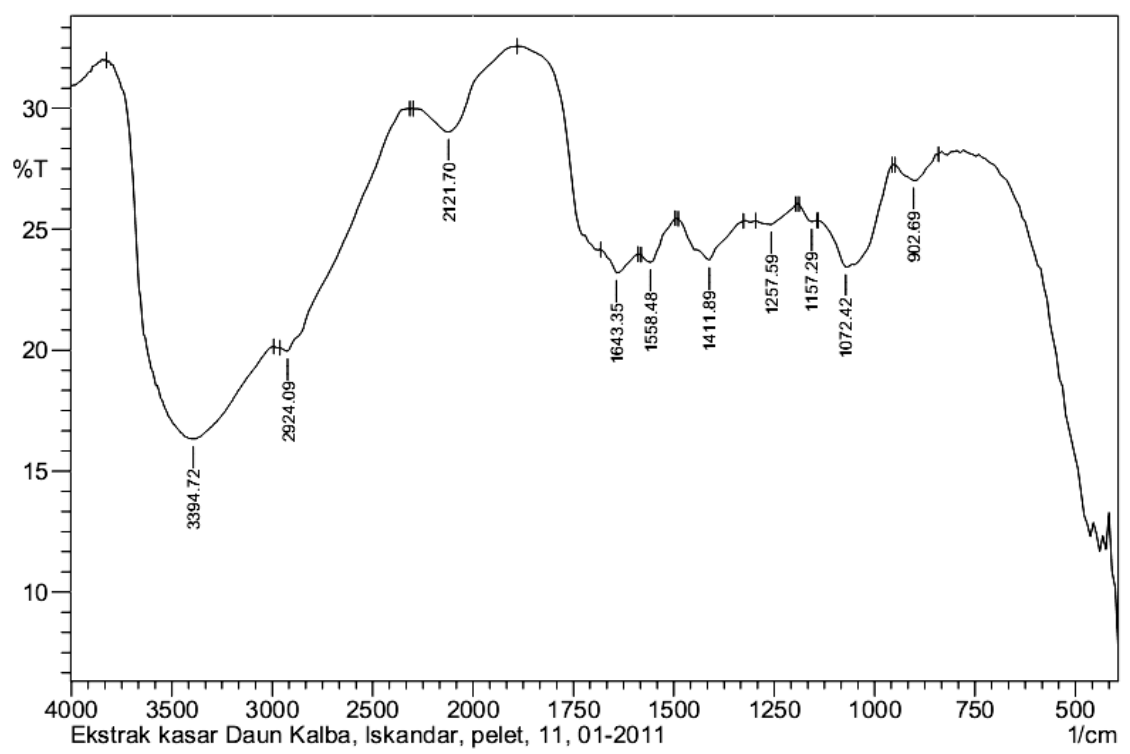

Gambar 11. Spektrum IR ekstrak E3 
Analisis spektrum IR Gambar 11 pada ekstrak metanol daun kalba menunjukkan adanya beberapa gugus fungsi. Vibrasi ulur $\mathrm{O}-\mathrm{H}$ dari ekstrak metanol daun kalba terlihat pada pita melebar di daerah 3200-3500 $\mathrm{cm}^{-1}$ dengan puncak serapan 3394,72 $\mathrm{cm}^{-1}$. Vibrasi ini menunjukkan adanya gugus $\mathrm{O}-\mathrm{H}$ yang membentuk ikatan hidrogen. Serapan pada bilangan gelombang 1257 $\mathrm{cm}^{-1}, \quad 1157 \mathrm{~cm}^{-1}$ dan $1072 \mathrm{~cm}^{-1}$ menunjukkan adanya gugus $\mathrm{C}-\mathrm{O}$.

Vibrasi ulur C-O dalam senyawaan fenolat menghasilkan pita kuat di daerah 1050-1260 $\mathrm{cm}^{-1}$. Serapan pada $1643 \mathrm{~cm}^{-1}$ menunjukkan $\mathrm{C}=\mathrm{C}$ aromatik, hal ini sesuai dengan spektrum UV-Vis yang menunjukkan adanya gugus kromofor $(\mathrm{C}=\mathrm{C})$ dimana terjadi transisi elektron dari $\mathrm{n} \rightarrow \pi^{*}$ atau $\pi \rightarrow \pi^{*}$. Serapan pada bilangan gelombang $902 \mathrm{~cm}^{-1}$ menunjukkan vibrasi ulur $\mathrm{C}-\mathrm{H}$ diluar bidang.

\section{KESIMPULAN DAN SARAN}

Berdasarkan hasil penelitian dapat disimpulkan sebagai berikut:

1. Ekstrak yang memiliki aktivitas paling tinggi diantara ketiga ekstrak daun kalba adalah ekstrak metanol dengan nilai $\mathrm{ES}_{50}$ sebesar 264,519 ppm.

2. Ekstrak metanol daun kalba mengandung senyawa metabolit sekunder golongan terpenoid, flavonoid, dan fenolat. Hasil analisis spektrofotometer FT-IR, Ekstrak metanol memiliki gugus fungsi antara lain $\mathrm{O}-\mathrm{H}, \mathrm{C}=\mathrm{C}$ aromatik, $\mathrm{C}-\mathrm{H}$ alifatik, $\mathrm{C}-\mathrm{H}$ dan $\mathrm{C}-\mathrm{O}$ dan berdasarkan hasil analisis spektrofotometer UV-Visibel memiliki gugus kromofor $\mathrm{C}=\mathrm{C}$.

\section{DAFTAR PUSTAKA}

Amic, D., D., Beslo, N., Trinajstic \& Davidovic, 2003, Structure-Radical Scavenging Activity Relationships of Flavonoids, Croatia Chem Acta, Vol. 76, No. 1, 55-61.

Atmosuseno, 1997, Budidaya, Kegunaan dan Prospek Sengon, Penebar Swadaya, Jakarta.

Blouis, M.S., 1958, Antioxidant Determinations by The Use of a Stable FreeRadical, Nature, 11991200.

Cholisoh, Z. \& W., Utami, 2008, Aktivitas Penangkap Radikal Ekstrak Ethanol 70\% Biji Jengkol (Archidendron Jiringa), Jurnal Pharmacon, Vol. 9, No. 1, 33-40.

Harborne, J. B., 1996, Metode Fitokimia Penuntun Cara Modern Menganalisa Tumbuhan, ITB, Bandung.

Khopkar, S.M., 2007. Konsep Dasar Kimia Analitik, UI Press, Jakarta.

Kusriniati, D., 2007, Pemanfaatan Daun Sengon (Albizia Falcataria) sebagai Pewarna Kain Sutera menggunakan Mordan Tawas dengan Konsentrasi yang Berbeda pada Busana Camisol, Skripsi, http://digilib.unnes.ac.id/gsdl/colle ct/skripsi/archives/HASH0150.dir/d oc. Pdf., Diakses Tanggal 22 Agustus 2010.

Molyneux, P., 2004, The Use of The Stable Free Radical Diphenylpicrylhydrazyl (DPPH) for Estimating Antioxidant Activity, $J$. Sci. Technol., http://www.sjst.psu.ac.th/journal/26 -2.pdf/07-DPPH.pdf., Diakses Tanggal 27 Agustus 2010. 
Prakash, A., F., Rigelhof \& E., Miller, 2001, Antioxidant Activity, http://www.medallionlabs.com/Dow nloads/Antiox_acti_.pdf.,

Diakses tanggal 28 Agustus 2010.

Purwati \& U., Rastuti, 2011, Uji Aktivitas Antioksidan Ekstrak Kulit Batang Kalba (Albizia Falcataria) dengan Metode DPPH (1,1-Difenil-2-Pikrilhidrazil) dan Identifikasi Senyawa Metabolit Sekundernya, Prosiding Seminar Nasional "Pengembangan Sumber Daya Pedesaan dan Kearifan Lokal Berkelanjutan", LPPM UNSOED, Purwokerto,
Rastuti, U. \& Purwati, 2010, Degradasi Lignin dari Serbuk Gergaji Kayu Kalba (Albizia falcataria) dan Uji Aktivitas Antioksidan dengan Metode TBA (Thio barbituric acid), Laporan DIPA I, Universitas Jenderal Soedirman 2010, 1 April 2010, Purwokerto.

Silverstein, R.M, G.C Bassler, T.C Morril, 1986, Penyidikan Spektrometrik Senyawa Organik. Hartomo AJ, penerjemah, Erlangga, Jakarta.

Sunarni, T., 2005, Aktivitas Antioksidan Penangkap Radikal Bebas Beberapa Kecambah dari Biji Tanaman Familia Papilionaceae, Jurnal Farmasi Indonesia, Vol. 2, No. (2), 53-61. 